\title{
KERJASAMA DAN BAGI HASIL ANTARA PEMILIK MODAL DENGAN PETANI KERAMBA IKAN NILA DI SUNGAI KAPUAS KOTA PONTIANAK
}

\author{
Eko Bahtiar \\ Fakultas Ekonomi dan Bisnis Islam IAIN Pontianak \\ ekogalaherang@gmail.com
}

\begin{abstract}
Abstrak
The main problem faced by cage farmers in running their business is that some of them have enough capital to build a productive business, but they do not have the skills to do it. Some have no capital but have the skills to work as cage farmers. On this basis, they then collaborated. The method used in this research is a qualitative method. The study was conducted in the Kapuas River, Tambelan Sampit Village, East Pontianak District, Pontianak City. The location selection was done purposively with the consideration that the area is a large area with tilapia fish farmers. The results showed that the cooperation carried out by capital owners with cage farmers in Tambelan Sampit village, the equipment used for the business came from owners of capital, while cage farmers as workers. In the collaboration, there is an unwritten agreement but it is well known in general that cage farmers do not share the risk if there is a loss, cage farmers also do not bear the costs of repairs if there is damage to the equipment used during the business. The amount of profit-sharing is determined based on mutual agreement, namely, profit divided by a 50\% margin for 50\% cage farmers for capital owners. Actions taken if one of the parties feels aggrieved include deciding the working relationship that can be carried out by the capital owner to the cage farmers in Tambelan Sampit already done based on or in accordance with the Islamic concept. Conformity is meant especially when compared with the principles of Muamalah taught by Islam.
\end{abstract}

Keyword: Capital Owners, Cooperation, Farmers

\section{PENDAHULUAAN}

Sebagaimana yang diketahui bahwa memajukan kesejahteraan umum merupakan salah satu tujuan nasional negara Republik Indonesia. Tujuan untuk memajukan kesejahteraan umum tersebut diamanatkan pada alinea ke empat dalam Pembukaan Undang-Undang Dasar 1945. Hanya saja, memuwujudkan tujuan tersebut bukanlah persoalan gampang, karena semua itu terkait dengan persoalan dana. Untuk itulah kemudian pemerintah berupaya menggali berbagai sumber dana yang diharapkan dapat dimanfaatkan bagi kesejahteraan masyarakat. Salah satu upaya yang dimaksud antara lain adalah menggali dan memanfaatkan sumber daya alam yang terdapat di laut.

Upaya untuk memanfaatkan laut sebagai sumber mata pencaharian merupakan upaya yang sangat positif, karena memang Indonesia adalah negara yang sebagian besar wilayahnya terdiri dari lautan dan menyimpan kekayaan yang tak ternilai harganya. Di sisi lain, kekayaan yang tersimpan di laut Indonesia sampai saat ini masih belum dimanfaatkan atau dikelola secara maksimal baik oleh pemerintah maupun oleh masyarakat. Banyak faktor yang 
menyebabkan beberapa komoditas laut tidak dapat dikelola secara maksimal. Faktor tersebut terutama berkaitan langsung dengan penguasaan teknologi masyarakat Indonesia yang relatif masih rendah.

Namun, dari sekian komoditas laut, ikan merupakan sumber mata pencaharian yang banyak diminati terutama oleh petani keramba. Selanjutnya, petani keramba merupakan profesi bagi yang menjadikan ikan sebagai sumber mata penceharian. Pekerja petani keramba adalah pekerja yang mulia. Hal ini disebabkan karena pekerjaan petani keramba tidak dapat dilakukan sambil lalu tanpa kesungguhan. Setiap petani keramba dalam melakukan kegiatan di laut memerlukan ketekunan, keuletan dan kerja keras. Pada umumnya petani keramba itu sendiri dalam melakukan akan berhadapan dengan tantangan dan cobaan terkait dengan kerasnya kehidupan di laut, seperti terjadinya gelombang, hujan disertai air pasang dan sebagaimananya.

Namun di sisi lain penghargaan terhadap profesi atau petani keramba baik oleh masyarakat maupun pemerintah masih relatif kecil. Hal ini dapat dilihat dari kebijakkan pemerintah yang kurang peka dengan masalah kelautan, khususnya kehidupan petani keramba. Dana yang masih minim untuk pembangunan di sektor kelautan khususnya bagi petani keramba itu sendiri, dan kebijakkan publik yang tidak berorientasi ke laut merupakan bukti ketidakpedulian yang dimaksud. Akibatnya, persoalan-persoalan yang dihadapi petani keramba tak kunjung habis. Persoalan-persoalan tersebut pada umumnya berkisar pada modal yang dibutuhkan oleh petani keramba untuk melanjutkan atau mengembangkan usahanya. Menyadari perlunya modal bagi kelangsungan usahanya, tak jarang petani keramba harus berurusan dengan pemilik modal.

Pada pengembangbiakan ikan, umumnya dilakukan oleh petani keramba di kelurahan Tambelan Sampit dan sekitarnya. Dengan cara keramba seperti ini dianggap sebagai upaya yang paling ekonomis. Jenis ikan yang diternaknya hanyalah ikan nila saja. Karena ikan nila merupakan ikan yang banyak peminatnya bagi masyarakat yang suka untuk mengkonsumsinya. Masa panen ikan nila ini biasanya berkisar waktu 3 sampai 4 bulan sekali.

Permasalahan yang dihadapi oleh petani keramba adalah modal yang dibutuhkan untuk pembuatan sarana menampung ikan nila, seperti tambak tancap atau biasa yang disebut dengan jaring. Tambak tancap merupakan wadah atau tempat tampung ikan nila yang terbuat dari tali yang berlubang kecil-kecil dengan tujuan agar bibit ikan nila yang disimpan di dalam tambak tersebut tidak mudah lepas. Sejak awal berdirinya usaha ternak ikan nila ini, petani keramba terlebih dahulu membuat keramba tancap sebanyak 8 petak, 1 petak ukurannya $4 \times 4$ meter dengan ketinggian 3 meter, dengan total keseluruhannya Rp. 12.500 .000 termasuk kayu, drum, tali dan bibit ikan nilanya.

Di sisi lain untuk membuat tambak baru, atau memperbaikinya membutuhkan biaya yang relatif mahal. Sementara itu, bagi petani keramba di Sungai Kapuas Kelurahan Tambelan Sampit, untuk memenuhi kebutuhan hidup sehari-hari saja sudah terasa sulit, apalagi untuk membuat atau memperbaiki jaring. Tetapi, bagaimanapun kondisinya jaring harus diperbaiki, sebab tanpa tambak tersebut petani keramba tidak akan bisa menampung dan memelihara ikan nila yang cukup banyak untuk mengembangbiakkan hasil ikan nilanya. Oleh karena itu, segala upaya pun dikerahkan termasuk harus menjalin kerja sama dengan pemilik modal yang memiliki persediaan modal (uang) cukup.

Bagi petani keramba di Sungai Kapuas khususnya Kelurahan Tambelan Sampit, terpaksa melaksanakan apapun bentuk konsekuensi sebagai akibat menjalin kerja sama 
dengan pemilik modal. Secara umum, konsekuensi yang harus diterima oleh petani keramba yaitu berkaitan dengan sistem bagi hasilnya. Petani keramba Kelurahan Tambelan Sampit yang menjalin kerja sama dengan pemilik modal hanya meminta modal untuk membuat atau memperbaiki tambak, lalu membeli bibit-bibit ikan nilanya, dan seluruh peralatan dibiayai oleh pemilik modal itu sendiri. Sedangkan petani kerambanya hanya mengelola usahannya saja. Apabila sesudah mendekati hasil panen, petani keramba dengan pemilik modal akan menjualnya kebersamaan dan hasilnya pun dibagi sesuai dengan kesepakatan bersama.

Kerjasama Pemilik Modal dan Petani Keramba di Kelurahan Tambelan Sampit, diketahui bahwa kerjasama tersebut dalam Islam dapat disebut Mudharabah. Disebut Mudharabah karena kerjasama tersebut bernilai ekonomis, dilakukan oleh satu orang saja (petani keramba) dan tujuan akhirnya untuk memperoleh keuntungan bersama. Bagi peneliti, pelaksanaan kerjasama usaha ternak ikan nila antara pemilik modal dengan petani keramba sebagaimana yang telah diuraikan di atas merupakan fenomena menarik untuk dikaji lebih mendalam terutama dengan menggunakan konsep ekonomi Islam sebagai tolak ukur. Diharapkan, setelah dilakukannya penelitian ini akan diketahui secara jelas apakah bentuk kerjasama, dan bagi hasil yang ditetapkan antara petani keramba dan pemilik modal sudah sesuai dengan konsep ekonomi Islam atau belum.

Berdasarkan latar belakang yang telah diuraikan di atas, maka penelitian ini difokuskan untuk mengkaji, "Pelaksanaan kerja sama usaha keramba ikan nila antara pemilik modal dengan petani keramba di Sungai Kapuas Kelurahan Tambelan Sampit Kecamatan Pontianak Timur Kota Pontianak”.

\section{METODE PENELITIAN}

Setiap penelitian memerlukan metode yang akan digunakan untuk mencari data dan menemukan jawaban terhadap masalah-masalah yang diteliti. Pendekatan dalam penelitian ini menggunakan penelitian kualitatif. Menurut Moleong (2001:3) penelitian kualitatif adalah penelitian yang menghasilkan data berupa kata-kata tertulis atau lisan dari orang-orang dan prilaku yang dapat diamati. Sedangkan Menurut Rasyid (2001:1) fenomenologi adalah, "memahami perilaku dari pola pikir menurut diri sendiri, dalam hal bagaimana kita melihat suatu gejala dan mencari "makna" dari gejala yang bersifat ajeg tersebut"

Penelitian ini dilakukan di Sungai Kapuas Kelurahan Tambelan Sampit Kecamatan Pontianak Timur Kota Pontianak. Pemilihan lokasi tersebut dilakukan secara purposive dengan pertimbangan daerah tersebut merupakan daerah yang banyak terdapat petani keramba ikan nila. Penelitian dilaksanakan bulan Agustus tahun 2019. Data dalam penelitian ini terdiri data primer dan data sekunder. Data primer diperoleh dari key informan melalui wawancara mendalam, sementara data sekunder diperoleh dari beberapa literatur terkait topik penelitian.

\section{HASIL DAN PEMBAHASAN}

\section{Bentuk Kerjasama yang Dilakukan Antara Pemilik Modal dengan Petani Keramba di Kelurahan Tambelan Sampit Sungai Kapuas}

Berdasarkan hasil wawancara di lapangan diketahui bahwa bentuk kerjasama yang dilakukan oleh pemilik modal dengan petani keramba ikan dalam pemenuhan perlengkapan pendirian usaha semua berasal dari pemilik modal. Adapun perlengkapan pendirian usaha tersebut seperti jaring, kerangka, pelampung, jangkar, bibit ikan, dan drum. Sedangkan petani 
keramba hanya sebagai pekerja. Dalam bentuk kerjasama ini ada sejumlah perjanjian tidak tertulis namun sudah diketahui secara umum.

Adapun beberapa perjajian tersebut di antaranya adalah petani keramba tidak ikut menanggung resiko jika terjadi kerugian, petani keramba juga tidak menanggung biaya perbaikan jika terjadi kerusakan pada peralatan yang digunakan selama berdirinya usaha tersebut dan petani keramba tidak boleh menjual hasil panen kepada siapapun, kecuali ada kesepakatan sebelumnya.

Melihat bentuk kerjasama yang diterapkan antara pemilik modal dengan petani keramba di Kelurahan Tambelan Sampit, menurut peneliti bentuk kerjasama ini sangat membantu bagi petani keramba yang tidak memiliki modal sendiri untuk mendirikan usaha ternak ikan nila ini. Dengan adanya bentuk kerjasama ini petani keramba dapat memenuhi kebutuhan hidup sehari-hari. Demikian halnya pula dengan pemilik modal, dengan adanya bentuk kerjasama seperti ini ia tidak perlu bersusah payah bekerja secara langsung, dan yang terpenting adalah ia sudah menolong petani keramba yang tidak memilik modal.

Harus diakui bahwa manusia dalam hidupnya memerlukan berbagai macam kebutuhan untuk tetap survive, baik itu berupa makanan, pakaian, maupun tempat tinggal. Di sisi lain, manusia diciptakan oleh Allah dengan berbagai kelebihan dan kekurangan. Dengan kelebihan dan kekurangan tersebut, manusia tidak selalu dapat memenuhi kebutuhan hidupnya secara individual. Kenyataanya menunjukkan bahwa ada manusia yang memliki kelebihan harta sehingga memiliki banyak modal, tetapi tidak bisa menjalankan usaha-usaha produktif. Ada orang yang memiliki modal besar, bisa berusaha produktif, namun berkeinginan untuk membantu orang lain yang memerlukan pekerjaan. Di sisi lain, tidak jarang pula ditemui orang-orang yang memiliki kemampuan dan keahlian berusaha secara produktif, tetapi tidak memiliki atau kekurangan modal. Berdasarkan kenyataan inilah, maka ada perlunya kerjasama antara orang yang memiliki modal dan orang yang memiliki keterampilan. Dengan adanya kerjasama tersebut, maka kebutuhan kedua belah pihak dapat terpenuhi. Hal ini tentunya sesuai dengan konsep bahwa manusia adalah makhluk sosial yang selalu memerlukan kehadiran manusia-manusia lain untuk memenuhi kebutuhan hidupnya.

\section{Analisis Kesesuaian dengan Konsep Ekonomi Islam}

Menurut peneliti, bentuk kerja antara pemilik modal dengan petani keramba di kelurahan Tambelan Sampit sudah sesuai dengan konsep ekonomi Islam. Alasan-alasan yang dapat peneliti kemukakan adalah:

\section{Orang-orang melakukan kerjasama sudah memenuhi syarat-syarat:}

1) Berakal

2) Baligh

3) Dengan kehendak sendiri (Lubis, 2000: 76)

\section{Adanya asas tolong menolong dalam kebaikan}

Bentuk kerjasama yang dilaksanakan dalam usaha ternak ikan nila ini antara pemilik modal dengan petani keramba di kelurahan Tambelan Sampit jelas mencerminkan asas tolong menolong. Dengan adanya bentuk kerjasama ini, petani keramba walaupun tidak memiliki modal sendiri namun dapat bekerja untuk memenuhi kebutuhan hidupnya sehari-hari. Bahkan, tidak sedikit di antara petani keramba tersebut dapat menyekolahkan anak-anaknya sampai ke perguruan tinggi. 


\section{Adanya asas keadilan}

Begitu pentingnya asas keadilan dalam Islam, kata keadilan disebut lebih dari 1.000 kali, menempati posisi terbanyak ketiga, setelah kata Allah dan ilmu pengetahuan. Menurut Ali (2000:116) asas keadilan asas sangat penting dalam hukum Islam dan karena itu asas keadilan dapat dikatakan sebagai asas semua asas hukum Islam. Asas keadilan dalam bentuk kerjasama ini tercermin dari bagi hasil yang ditetapkan yaitu 50\% untuk petani keramba dan 50\% untuk pemilik modal. Shihab (1999: 114) membagi makna adil menjadi empat. Pertama, adil dalam arti "sama", yaitu persamaan dalam hak. Dalam surat An-Nisa' ayat 58 dinyatakan bahwa:

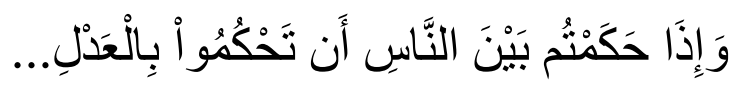

Artinya:

"Apabila kamu memutuskan perkara di antara manusia, maka hendaklah engkau memutuskannya dengan adil".

Menurut M. Quraish Shihab, kata adil pada ayat di atas dapat diartikan sama, namun hanya mencakup sikap dan perlakukan hakim pada saat proses pengambilan keputusan.

\section{Adanya asas manfaat.}

Adanya asas manfaat dalam bentuk kerjasama yang dilakoni oleh pemilik modal dan petani keramba tercermin dari tujuan dari dilaksanakannya kerjasama ini, yaitu untuk memperoleh penghasilan yang nantinya digunakan untuk memenuhi kebutuhan hidup masingmasing pihak (petani keramba dan pemilik modal). Menurut Alim (2010: 152) di antara asasasas hukum Islam, ada asas yang paling utama, yaitu asas keadilan, dan asas kemanfaatan

\section{Perjanjian dalam Kerjasama dan Kesesuaiannya dengan Konsep Ekonomi Islam Kewajiban menepati perjanjian}

Menyangkut apa yang telah dijanjikan, masing-masing pihak harus saling menghormati dalam arti mentaati yang telah dijanjikan tersebut. Mengenai hal ini Allah SWT, berfirman dalam surat Al-Maidah ayat 1yaitu:

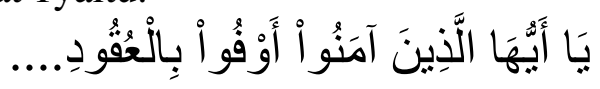

Artinya:

Hai orang-orang yang beriman, penuhilah akad-akad itu". (Depag, RI, 1989:156) Menurut Pasaribu dan Lubis (1992: 2) yang dimaksud dengan akad pada ayat di atas adalah janji setia kepada Allah dan juga meliputi perjanjian yang dibuat oleh manusia dengan sesama manusia dalam pergaulannya sehari-hari. Berdasarkan ayat di atas, menjadi jelas bahwa Islam memerintahkan kepada umatnya agar senantiasa memenuhi janji. "Janji adalah utang", demkian bunyi falsafah yang sering diungkapkan oleh banyak orang. Menurut Shihab (1999: 258) bahwa keengganan memenuhi janji merupakan dosa, bahkan salah satu tanda kemunafikan. Dalam konteks pengingkaran janji, Nabi Muhammad pernah bersabda yang diriwayatkan oleh Bukhori dan Muslim melalui Abu Hurairah, Artinya: Tanda orang munafik itu ada tiga. Apabila dia berbicara, dia berbohong, apabila ia berjanji dia tidak menepati, dan apabila diamanati dia khianat”. (HR. Bukhari Muslim).

Berdasarkan kutipan di atas, yang harus dilakukan baik oleh petani keramba maupun pemilik modal adalah menepati janji-janji atau kesepakatan yang telah dibuat sebelumnya. Ini dilakukan selain karena memang sudah merupakan suatu kewajiban, juga demi menjaga 
hubungan baik antara pemilik modal dan petani keramba, serta agar tidak merugikan salah satu pihak (petani keramba atau pemilik modal).

\section{Syarat-syarat sah perjanjian}

Menurut Sari (2017:81) Suatu kontrak atau perjanjian menjadi sah dan mengikat secara hukum bagi para pihak yang membuatnya. Selanjutnya agar sebuah perajanjian menjadi sah, maka ada sejumlah syarat yang harus dipenuhi. Menurut Sayyid Sabiq sebagaimana dikutip oleh Pasaribu dan Lubis (1996: 2), secara umum yang menjadi syarat sahnya sebuah perjanjian adalah: tidak menyalahi hukum syari'ah yang telah disepakati. Perjanjian yang dibuat oleh kedua belah pihak bukanlah perjanjian yang bertentangan dengan hukum atau perbuatan sebagaimana digariskan syari'ah. Perjanjian yang bertentangan dengan ketentuan hukum syari'ah adalah tidak sah, dan dengan sendirinya tidak ada kewajiban bagi masing-masing pihak untuk menepati atau melaksanakan perjanjian tersebut.

\section{Harus sama ridha dan ada pilihan}

Perjanjian yang dibuat harus didasarkan pada kesepakatan bersama oleh kedua belah pihak. Dalam hal ini berarti tidak dibenarkan adanya unsur paksaan oleh satu pihak kepada pihak lain. Dengan kata lain, perjanjian yang dibuat harus merupakan kehendak bebas dari masing-masing pihak.

\section{Harus jelas dan gamblang}

Apapun yang diperjanjikan oleh para pihak yang membuat perjanjian harus jelas tentang apa yang menjadi isi perjanjian, sehingga tidak menimbulkan kesalahpahaman di kemudian hari. Berdasarkan keterangan di atas, dapat disimpulkan bahwa apapun bentuk dan tujuan dari perjanjian yang dibuat baru dapatkan dikatakan sah apabila memenuhi syaratsyarat tersebut.

\section{Analisis Kesesuaian Perjanjian Dengan Konsep Ekonomi Islam}

Menurut peneliti, perjanjian-perjanjian yang dilakukan antara pemilik modal dengan petani keramba dalam kerjasama pada usaha ternak ikan nila di kelurahan Tambelan Sampit sudah sesuai dengan konsep ekonomi Islam. Kesesuaian tersebut terutama jika dibandingkan dengan syarat-syarat sahnya sebuah perjanjian, yaitu:

\section{Perjanjian dilakukan dalam bidang pekerjaan yang sah}

Dalam rangka untuk memenuhi kebutuhan hidupnya, manusia diperintahkan oleh Allah untuk bekerja. Menurut Madjid (2000: 30) sepanjang ajaran Islam kerja adalah hakikat keberadaan manusia. Al-Qur'an juga dengan tegas memerintahkan manusia untuk bekerja sebagaimana tercantum dalam surat At-Taubah ayat 105 yang artinya, "Bekerjalah kamu, maka Allah dan Rasul-Nya serta orang-orang yang beriman akan melihat pekerjaanmu itu". Apapun jenis pekerjaan selama baik dan halal pada dasarnya boleh dilakukan, termasuk bekerja sebagai petani keramba.

\section{Adanya kerelaan kedua belah pihak}

Perjanjian-perjanjian yang dilakukan antara pemilik modal dengan petani keramba di kelurahan Tambelan Sampit sudah dilakukan atas dasar suka sama suka. Adanya kerelaan 
atau suka sama suka tercermin dari tidak adanya keluhan baik dari pihak petani keramba maupun dari pemilik modal selama dilakukannya wawancara.

\section{Isi perjanjian jelas}

Menurut peneliti, perjanjian yang ditetapkan selama berlangsungnya kerjasama antara pemilik modal dengan petani keramba sudah jelas, sehingga setiap petani keramba dapat memahaminya dengan mudah baik terhadap isi maupun akibat dari perjanjian tersebut. Selain sudah adanya kesesuaian dengan konsep ekonomi Islam., perjanjian yang disepakati oleh petani keramba dengan pemilik modal, menurut peneliti, masih ada ketidaksesuainnya dengan konsep ekonomi Islam. Ketidaksesuaian yang peneliti maksud adalah "perjanjian tidak dilakukan secara tertulis". Hal ini tentunya bertentangan dengan ajaran Islam sebagaimana tercantum dalam Al-Qur'an surat Al-Baqarah ayat 282:

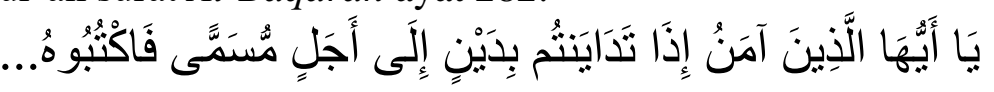

Artinya:

"Wahai orang-orang yang beriman, apabila kamu bermuamalah tidak secara tunai untuk waktu yang telah ditentukan, hendaklah kamu menuliskannya".

Berdasarkan ayat di atas, menjadi jelas bahwa apapun kegiatan muamalah termasuk di dalamnya kegiatan perjanjian seharusnya dilakukan secara tertulis. Ini dilakukan selain untuk memperkuat perjanjian, juga untuk menghindari agar hal-hal yang tidak inginkan tidak terjadi.

\section{Besaran Bagi Hasil yang Ditetapkan Antara Pemilik Modal dengan Petani Keramba}

Berdasarkan hasil wawancara baik dengan petani keramba maupun dengan pemilik modal diketahui bahwa besaran bagi hasil yang ditetapkan berdasarkan kesepakatan bersama, yaitu dengan prosentase 50\% untuk pekerja (petani keramba) dan 50\% untuk pemilik modal. Menurut Siddiqi (1996: 16) bahwa ulama Fiqh yang sepakat bahwa tidak ada jumlah yang pasti yang dapat ditetapkan bagi pihak mudharabah (bagi hasil). Sehingga, menurut beliau, dalam pembagian keuntungan, pihak-pihak yang menjalin kerjasama bisa menetapkan berapapun bagian tersebut melalui perjanjian bersama.

Berdasarkan hasil penelitian di lapangan diketahui bahwa besaran bagi hasil yang ditetapkan antara petani keramba dengan pemilik modal di kelurahan Tambelan Sampit sudah sesuai dengan asas-asas keadilan dan kelayakan. Asas keadilan yang dimaksud tercermin dari upah atau bagi hasil yang diperoleh petani keramba sesuai dengan haknya. Sebagaimana diketahui bahwa adil tidak harus berarti sama, tetapi adil di sini berarti memberikan sesuatu kepada orang lain sesuai dengan haknya. Asas kelayakan tercermin dari tercukupinya kebutuhan hidup para petani keramba walaupun hanya mendapat bagian 50\%. Asas kebajikan tercermin dari bidang pekerjaan yaitu sah menurut hukum agama, adanya kerelaan kedua belah pihak, dan isi kesepakatan cukup jelas.

\section{Tindakan yang Dilakukan Jika Salah Satu Pihak Merasa Dirugikan}

Melaksanakan suatu usaha kerja sama sangat memungkinkan akan terjadi berbagai hal yang tidak diinginkan sebagai akibat salah satu pihak yang menjalin kerjasama melanggar kesepakatan yang telah dibuat sebelumnya. Demikian halnya pula dengan usaha kerjasama yang dilakukan oleh petani keramba dengan pemilik modal di kelurahan Tambelan Sampit. Ketika sudah terjalin kerjasama maka akan berlaku hak dan kewajiban yang harus dipatuhi 
baik oleh petani keramba maupun pemilik modal. Jika salah satu pihak tidak melaksanakan perjanjian yang telah dibuat sebelumnya, maka perjanjian dinyatakan batal. Mengenai batalnya perjanjian, menurut pendapat Pasaribu dan Lubis (1996: 5) apabila salah satu pihak telah melakukan perbuatan menyimpang dari apa yang telah dijanjikan, maka pihak lain dapat membatalkan perjanjian tersebut. Lebih lanjut dijelaskan bahwa apabila salah satu pihak melakukan sesuatu kecurangan dan ada bukti-buktinya, maka perjanjian juga dibatalkan oleh pihak yang lainnya.

Berdasarkan pendapat tersebut menjadi jelas bahwa kejujuran merupakan modal utama dalam kerjasama. Dengan kejujuran akan terbangun saling percaya diantara kedua belah pihak. Jika kepercayaan sudah terbangun, maka kedua belah pihak dapat menjalin kerjasama dalam waktu lama, dapat melaksanakan hak dan kewajiban masing-masing dengan tenang, dan tidak akan muncul kecurangan. Sebagaimana diketahui bahwa Islam adalah agama yang mengajarkan agar umat manusia agar selalu melaksanakan amanat dengan baik dan benar. Amanat meliputi apa saja yang dipertanggungjawabkan oleh seorang, baik pekerjaan, perkataan, maupun kepercayaan.

Di kelurahan Tambelan Sampit, sebenarnya juga sudah berlaku suatu ketetapan bahwa jika pemilik modal merasa dirugikan karena petani keramba tidak melaksanakan kewajibannya dengan baik atau tidak mematuhi perjanjian yang telah dibuat sebelumnya, maka pemilik modal dapat memutuskan hubungan kerja dengan petani keramba yang bersangkutan. Hanya saja, karena perjanjian-perjanjian tidak dilakukan secara tertulis, maka baik petani keramba maupun pemilik modal tidak dapat menyelesaikan persoalan yang muncul melalui jalur hukum. Karenanya, penyelesaian masalah secara kekeluargaan selalu merupakan langkah sebelum dilakukannya pemutusan hubungan kerja secara sepihak.

\section{KESIMPULAN DAN SARAN}

Berdasarkan paparan data yang telah diuraikan, maka kesimpulnya sebagai berikut: Kerjasama yang dilakukan pemilik modal dengan petani keramba di kelurahan Tambelan Sampit dalam segala bentuk peralatan yang digunakan untuk mendirikan usaha keramba ikan nila berasal dari pemilik modal, sedangkan petani keramba sebagai pekerja. Besaran bagi hasil yang ditetapkan berdasarkan kesepakatan bersama yaitu $50 \%$ untuk petani keramba dan 50\% untuk pemilik modal. Adapun Tindakan yang dilakukan ketika salah satu pihak merasa dirugikan di antaranya memutuskan hubungan kerja yang dapat dilakukan oleh pemilik modal terhadap petani keramba maupun sebaliknya. Pemutusan hubungan kerja dipilih dengan cara penyelesaian kekeluargaan. Adapun saran yang dapat peneliti sampaikan bagi pemilik modal dan petani keramba sebaiknya membuat perjanjian secara tertulis.

\section{DAFTAR PUSTAKA}

Ali, MD. (2000). Hukum Islam. Jakarta: PT Raja Grafindo Persada.

Alim. M. (2010). Asas asas hukum modern dalam hukum Islam. Jurnal Media Hukum 17 (1 ), 153-159.

Harun, R. (2000). Metode Penelitian Kualitatif Bidang Ilmu Sosial dan Agama, Pontianak: Kopma STAIN.

Lubis, SK. (2000). Hukum Ekonomi Islam. Jakarta: Sinar Grafika. 
Madjid, N. (2000). Islam Agama Peradaban: Membangun Makna dan Relevansi Doktrin Islam Dalam Sejarah. Jakarta: Paramadina.

Moleong, LJ. (2001). Metedologi Penelitian Kualitatif. Bandung: PT. Remaja Rosdakarya.

Pasaribu, C \& Lubis, SK. (1996). Hukum Perjanjian Dalam Islam. Jakarta: Sinar Grafika.

Sari, N. R.. (2017). Komparasi syarat sah perjanjian menurut kitab undang-uundang hukum perdata dan hukum Islam. Jurnal Repertorium, 4 (2), 81-85.

Shihab, MQ. (1999). Wawasan Al-Qur'an. Bandung: Mizan.

Shihab, MQ. (1999). Fatwa-fatwa M. Quraish Shihab: Seputar Ibadah dan Muamalah. Bandung: Mizan.

Siddiqi, MN. (1996). Kemitraan Usaha dan Bagi Hasil dalam Hukum Islam, Yogyakarta: PT. Dana Bhakti Prima Yasa. 